\title{
ANTIBIOTIC TREATMENT ACCORDING TO PROCALCITONIN AND C- REACTIVE PROTEIN LEVELS
}

\author{
ADELINE LARISA HORGA ${ }^{1}$, MIHAI LEONIDA NEAMȚU ${ }^{2}$ \\ ${ }^{1}$ PhD Candidate, “Lucian Blaga” University of Sibiu, " “Lucian Blaga” University of Sibiu
}

Keywords: $\begin{array}{rr}\text { procalcitonin, } \\ \text { antibiotics, }\end{array}$ infection

\begin{abstract}
Respiratory tract infections are the most common infections find at pediatric age. Children with lower respiratory tract infections can presents severe forms, which is why early diagnosis and treatment are essential. Choosing the therapy is made according to the etiology, but at the time of admission it is difficult to establish the etiology of the disease and for this reason, most often, it is decided to initiate the antibiotic therapy. Excessive antibiotic prescription, in cases that it is not justified, is really a problem because it contributes to the increase of antimicrobial resistance. A study was conducted in order to limit the hypothesis of prolonged antibiotic therapy, which also prolongs the duration of hospitalization. By anticipating $C$-reactive protein and procalcitonin levels we could guide or reconsider the antibiotic treatment.
\end{abstract}

\section{INTRODUCTION}

Pneumonia is a common respiratory tract infection in children, especially in infant.(1) In most of the cases the etiology is viral and the antibiotic therapy is not necessary $(2,3)$, but is still a challenge to know the etiology in the moment of the admission in hospital. This cannot be done only after the clinical examination of the patient. The most of the patients with acute community-acquired pneumonia are receiving antibiotic treatment, which has led to excessive antibiotic prescribing, contributing to increased antibacterial resistance. $(4,5)$

In literature, there are published numerous studies which have been performed with the purpose to differentiate a bacterial infection from a viral infection using the inflammatory markers, in order to reduce the antibiotics prescription.(6-11) Procalcitonin is a studied biomarker in last years in terms of guiding antibiotic treatment taking into account its values. Along with $\mathrm{C}$-reactive protein, they have proven their importance in terms of diagnosing infections of bacterial etiology and also their utility in the therapeutic decision.(12-14)

\section{MATERIALS AND METHODS}

An observational prospective study developed in Sibiu Pediatric Clinic, over a period of 2 years, which included patients under the age of 18 diagnosed with acute pneumonia. At admission, at 72 hours and before discharge, procalcitonin and C-reactive protein were determined. In addition to these biological parameters, it was determined complete blood count, usual biochemical laboratory analyses, also obtained demographic data, general anamnestic data and those related to current pathology and, last but not least, the therapeutic and evolutionary parameters that include antibiotic therapy.

Using the interpretation of the chest $\mathrm{X}$ ray performed at admission, the subjects were divided in two groups: group with bacterial pneumonia (group A) and a group with viral pneumonia (group B). Therapeutic parameters (type and duration of treatment) were evaluated in two stages: at admission and after that, at check-up 1 and 2 (72 hours, respectively at discharge). The aim of the study is to limit the hypothesis of prolonged antibiotic therapy and also prolongs the duration of hospitalization. By anticipating C-reactive protein and procalcitonin levels, we could reconsider the antibiotic treatment.

\section{RESULTS AND DISCUSSIONS}

Therapeutic parameters (antibiotic therapy) were evaluated in two stages: at admission, when it was initiate the treatment, respectively after 72 hours (check-up 1) and at discharge (check-up 2).

1. Evaluation at admission:

Antibiotic therapy was initiated in both groups in the same proportion $(\mathrm{p}=0.18)$.

- $\quad$ as expected, monotherapy was significantly more common in patients with viral pneumonia $(\mathrm{p}=0.00008)$, and the combination of two $(\mathrm{p}=0.0001)$ and three $(\mathrm{p}=0.02)$ antibiotics was significantly more common in patients with bacterial pneumonia. Speculation is only comparative and preliminary, because viral pneumonia does not require antibiotic therapy when the etiology is clearly proven;

- when C-reactive protein values were slightly increased, patients with viral pneumonia were initiated with either monotherapy or combinations of two antibiotics, both decisions being statistically significant $(\mathrm{p}<0.0000001$ and $\mathrm{p}=0.0003$, respectively);

- when the values of procalcitonin and C-reactive protein were moderately/ severely increased, patients with bacterial pneumonia received either monotherapy or combinations of two antibiotics, both decisions being statistically significant ( $\mathrm{p}<0.001$ and $\mathrm{p}=0.012$, respectively);

- when C-reactive protein or procalcitonin values showed an extreme increase, the combination of two antibiotics was

${ }^{1}$ Corresponding author: Adeline Larisa Horga, Str. Andrenyi Karoly, Nr.2 - 4, Arad, România, E-mail: horga_adeline@yahoo.com, Phone: +40722 113112

Article received on 29.07.2021 and accepted for publication on 02.09.2021 


\section{CLINICAL ASPECTS}

significantly the most common decision $(\mathrm{p}=0.0001)$.

2. Evaluation at 72 hours (check-up 1) and at discharge (check-up 2):

The average duration of antibiotic therapy was 12.3 days in patients with bacterial pneumonia and 9.2 days in patients with viral pneumonia. So, significant trend for longer duration of antibiotic therapy in patients with bacterial pneumonia compared to patients with viral pneumonia.

- anticipation of $\mathrm{C}$-reactive protein and procalcitonin values could allow a decrease of $43.47 \%(\mathrm{p}=0.00004)$ in monotherapy in bacterial pneumonia and by $70.96 \%$ ( $\mathrm{p}=$ 0.0001 ) in viral pneumonia; the decrease is also allowed in the combination of two antibiotics, respectively by $31.42 \%$, in bacterial pneumonia $(\mathrm{p}=0.00002)$ and by $15 \%$ in viral pneumonia $(\mathrm{p}=0.0001)$;

- $\quad$ at check-up 1, the most frequent and extremely significant situations $(\mathrm{p}<0.0000001)$ were those in which the therapeutic scheme from hospitalization was continued, in the conditions of decrease (bacterial pneumonia) or not of the values of reactive protein $\mathrm{C}$ (viral pneumonia );

- at check-up 2, the comparative analysis was statistically significant for discontinuation of antibiotic therapy one day before discharge in patients with viral pneumonia $(\mathrm{p}=$ $0.03)$.

3. Antibiotic therapy compared with procalcitonin values (duration of antibiotic treatment)

- $\quad$ according to the value of procalcitonin from check-up 1 , the relationship between procalcitonin and the duration of antibiotic therapy is strong, positive and extremely statistically significant ( $\mathrm{p}<0.00001)$;

- $\quad$ according to the value of procalcitonin from check-up 2, the relationship between procalcitonin and the duration of antibiotic therapy is negligible, negative and without statistical significance $(\mathrm{p}=0.877)$;

- $\quad$ the fact that the procalcitonin ratio is stronger at check-up 1 than at check-up 2 and is negative at check-up 2 proves that the duration of antibiotic therapy is prolonged despite the normalization of procalcitonin values, a situation often encountered in medical practice.

4. The anticipated regime of administration of

\section{antibiotic therapy}

- by anticipating the values of C-reactive protein and procalcitonin, in group A, out of 46 patients with monotherapy, 20 should have remained (a decrease of $43.47 \%)$. The difference is statistically significant $(\mathrm{OR}=$ $3.759,95 \%$ CI: $1.956-7.222, p=0.00004)$. In group $B$, out of 93 patients with monotherapy, 66 should have remained (a decrease of $70.96 \%$ ). The difference is also statistically significant $(\mathrm{OR}=2,931,95 \% \mathrm{CI}: 1,654-5,192, \mathrm{p}=0.0001)$.

- by anticipating C-reactive protein and procalcitonin values, in group $\mathrm{A}$, out of 35 patients with a combination of 2 antibiotics, 11 should have remained (a decrease of $31.42 \%)$. The difference is statistically significant $(\mathrm{OR}=$ $4.65,95 \%$ CI: $2,167-9,981, p=0.00002)$. In group B, out of 20 subjects with a combination of 2 antibiotics, 3 should have remained (a 15\% decrease). The difference is statistically significant $(\mathrm{OR}=7.823,95 \%$ CI: 2,257-27.11, $\mathrm{p}=0.0001$ ).

- following control 1, 61 patients remained with the same treatment, in 5 patients received one more antibiotic, in 1 patient one antibiotic was discontinued and changed the antibiotic that remain, in 2 patients the antibiotic was changed. The comparative analysis showed that the patients in group $\mathrm{B}$ who continued the treatment after hospitalization, given that the values of C-reactive protein remained unchanged, are extremely numerous more than the patients in group A $(\mathrm{p}<0.0000001)$, respectively, that patients in group A who continued the treatment regimen after hospitalization, even if the values of C-reactive protein (and procalcitonin) decreased, are extremely significantly more numerous than patients in group $\mathrm{B}(\mathrm{p}$ $<0.0000001$ ).

- by anticipating the values of C-reactive protein and procalcitonin in group A, 7 more subjects could have been minimally modified (in the sense of decreasing the number of antibiotics in the combination), without statistical significance $(\mathrm{OR}=0.6904,95 \%$ CI: $0,3037-1,569, \mathrm{p}=$ 0.2 ), and in group B another 14 subjects, with statistical significance $(\mathrm{OR}=0.1499,95 \%$ CI: $0.0638-0.5951, \mathrm{p}=$ 0.001 )

- following control 2, the antibiotic was discontinued in 3 patients in group B.

- following control 2, it was found that in 73 patients, from group $\mathrm{A}$, the antibiotic was discontinued on the day of discharge, at 8 in the day before the discharge, and at 6 at more than one day after discharge. In group B, in 83 patients the antibiotic was discontinued on the day of discharge, at 24 on the day before the discharge, and in 8 at more than one day after discharge.

\section{CONCLUSIONS}

Following the study, statistically significant values were obtained regarding antibiotic treatment taking into account the values of procalcitonin and c-reactive protein. The decision to discontinue antibiotic therapy one day before discharge in patients with viral pneumonia $(p=0.03)$ was significantly statistic. The expected values of $\mathrm{C}$-reactive protein and procalcitonin could have significantly reduced the antibiotic prescription.

\section{REFERENCES}

1. Principi N, Esposito S. Management of severe communityacquired pneumonia of children in developing and developed countries, Thorax 2010, Epub Oct 21, 66(9):815-22.

2. Cevey-Macherel M, Galetto-Lacour A, Gervaix A, Siegrist CA, Bille J, Bescher-Ninet $B$, et al. Etiology of community-acquired pneumonia in hospitalized children based on WHO clinical guidelines, Eur J Pediatr 2009, 168:1429-36

3. Cilla G, On ate E, Perez-Yarza EG, Montes M, Vicente D, Perez- Trallero E. Viruses in community-acquired pneumonia in chil- dren aged less than 3 years old. High rate of viral coinfection, J Med Virol. 2008;890:1843-9.

4. Esposito S, Blasi F, Allegra L. Principi N and the Mowgli Study Group. Use of antimicrobial agents for communityacquired lower respiratory tract infections in hospitalised children, Eur J Clin Microbiol Infect Dis. 2001;20:647-50.

5. Nascimento-Carvalho CM. Pharmacotherapy of childhood pneumonia, Expert Opin Pharmacother. 2010;11:225-31.

6. Gendrel D, Raymond J, Coste J, Moulin F, Lorrot M, Guerin S, et al. Comparison of procalcitonin with Creactive protein, interleukin 6 and interferon-alpha for differentiation of bacterial vs viral infections, Pediatr Infect Dis J. 1999;18:875-81.

7. Khan DA, Rahman A, Khan FA. Is procalcitonin better than C- reactive protein for early diagnosis of bacterial pneumonia in children? J Clin Lab Anal. 2010;24:1-5.

8. Korppi M, Heikanen-Kosma T, Leinonen M. White blood cells, C- reactive protein and erythrocyte sedimentation rate in pneu-mococcal pneumonia in children, Eur Resp J. 1997;10:1125-9.

9. Moulin F, Raymond J, Lorrot M, Marc E, Coste J, Iniguerz 


\section{CLINICAL ASPECTS}

$\mathrm{J}$, et al. Procalcitonin in children admitted to the hospital with community acquired pneumonia, Arch Dis Child. 2001;84:332-6.

10. Nohynek H, Valkeila E, Leinonen M, Eskola J. Erythrocyte sedimentation rate, white blood cell count and serum Creactive protein in assessing etiologic diagnosis of acute lower respiratory infections in children, Pediatr Infect Dis J. 1995;14:484-90.

11. Toikka $\mathrm{P}$, Irjala $\mathrm{K}$, Juve' $\mathrm{n} \mathrm{T}$, Virkki R, Mertsola $\mathrm{J}$, Leinonen M, et al. Serum procalcitonin, C-reactive protein and interleukin- 6 for distinguishing bacterial and viral pneumonia in children, Pediatr Infect Dis J. 2000;19:598602.

12. Koenig SM, Truwit JD. Ventilator-associated pneumonia: diagnosis, treatment, and prevention, Clin Microbiol Rev. 2006; 19:637-657.

13. Schuetz P, Chiappa V, Briel et al. Procalcitonin algorithms for antibiotic therapy decisions: a systematic review of randomized controlled trials and recommendations for clinical algorithms, Archives of Internal Medicine. 2011;171(15):1322-1331.

14. Carr JA. Procalcitonin-guided antibiotic therapy for septic patients in the surgical intensive care unit, Journal of Intensive Care. 2015;3:36. 